\title{
Thematic Issue on Snow Resources and Hydrological Cycle
}

\author{
Massimiliano Zappa ${ }^{1 *}$, Ladislav Holko², Martin Šanda ${ }^{3}$, Tomáš Vitvar ${ }^{3,5}$, Juraj Parajka ${ }^{4}$ \\ ${ }^{1}$ Swiss Federal Research Institute WSL, Zürcherstrasse 111, 8903 Birmensdorf, Switzerland. \\ ${ }^{2}$ Slovak Academy of Sciences, Institute of Hydrology, Dúbravská cesta 9, 84104 Bratislava, Slovakia. \\ ${ }^{3}$ Czech Technical University in Prague, Thákurova 7, 16629 Prague 6, Czech Republic. \\ ${ }^{4}$ Institute of Hydraulic Engineering and Water Resources Management, Vienna University of Technology, Vienna, Austria. \\ ${ }^{5}$ Escuela Superior Politécnica del Litoral, Guayaquil, Ecuador. \\ * Corresponding author. E-mail: massimiliano.zappa@wsl.ch
}

\section{INTRODUCTION}

The importance of snow in the local, regional and global cycles of freshwater is highly acknowledged (Lemke et al., 2007). In many areas of the world freshwater first accumulates in form of snow and later releases the meltwater to soils, groundwater, reservoirs and rivers.

The assessment of the impact of global warming on snow and in general on the cryosphere should be supported by high quality observations (Vaughan et al., 2013). Barnett et al. 2005 stated that the impacts of global climate change are mostly relevant for the areas where water and snow resources are closely linked, such as in the mountains of the Central and Eastern Europe (Marty et al., 2017). However, Klemeš (1990) considered mountains highly challenging in the perspective of description of hydrological processes and modelling. This is mostly linked with highly variable topography, land cover and soil properties and the complex interaction between climate and landscape elements in these environments (Gurtz et al., 1999).

Snowmelt is the key governing variable in shaping the regime of many rivers (Barnhart et al., 2016). It is predicted that the climate change will cause an increase of liquid precipitation at the cost of solid precipitation (Berghuijs et al., 2014). Therefore, sound analyses and modelling experiments are needed to understand how changing snow resources will change the way water is managed in mountain regions and in the regions where the supply of water for population, irrigation and hydro energy is linked with the seasonal dynamic of snowpack (Mankin et al., 2015; Viviroli et al., 2011). Besides the snowmelt induced floods (Vormoor et al., 2016), recent studies also highlight the role of snow cover and glaciers in soil and groundwater recharge (Jasechko et al., 2014) and hydrological drought (Fraser, 2012; Godsey et al., 2014; Jenicek et al., 2016, Van Loon et al., 2014). Field measurements of snow characteristics provide key data to calculate the amount of water stored in the snow cover, the rate of its release during the snowmelt and validation of snow models or remote sensing products. Modelling is an important tool in the research of the hydrological cycle and forecasting of the variability of its components including floods and droughts, snow and snowmelt runoff modelling (e.g. Etchevers et al., 2002; Hock, 2003; Kirnbauer et al., 1994; Martinec and Rango, 1986) benefit from the remote sensing products and it is therefore natural that hydrologists continuously try to improve model performance also by incorporating the remote sensing data (e.g. Parajka and Blöschl, 2008; Thirel et al., 2013).

This thematic issue on snow resources and hydrological cycle includes 14 authors from 14 European countries. It was designed to attract contributions on the current state of measurement and modeling of snow cover characteristics, amount and variability of water stored in snow, its release during the snowmelt and the links between the snow cover and hydrological processes. Furthermore, this collection of original articles represents a dissemination outcome of the Swiss-CzechGeorgian collaborative project focused on "Snow resources and the early prediction of hydrological drought in mountainous streams" (SREP-Drought, Zappa et al., 2015), supported by the Swiss National Science Foundation. The objective of that project was to evaluate how summer low flows and droughts are affected by winter snowpack in three mountain catchments located in the Alps (Prealps, central Switzerland, Hegg et al., 2006), in the Jizera Mountains (Kamenice, northern Czech Republic; Šanda et al., 2014), and in the Little Caucasus (Gudjaretis-Tskali, central Georgia, Melikadze et al., 2013). Some of the articles in this collection well align on the project topics and thus contribute to the know-how exchange among the European scientists. Four studies in this issue are devoted to measurements of snow characteristics in the field or their estimation from the remote sensing. Four studies are focused on sampling snow or meltwater for isotope analyses or the use of isotopic approaches in studying the hydrological cycle. Finally, three studies are devoted to snowmelt modelling and use of remote sensing data.

\section{FIELD SNOW DATA COLLECTION}

Bartík et al. (this issue) analyse the influence of the spruce forest dieback on snow characteristics (depth, density, water equivalent) in the highest part of the Carpathian Mountains (northern Slovakia). Data from five winter seasons showed that the difference in snow depth between the disturbed and living forest increased since the third winter after forest dieback. The forest dieback resulted in a significant increase (about 25\%) of the water amount stored in the snow while the snowmelt characteristics (snowmelt beginning and time of snow disappearance) did not change substantially.

Komarov et al. (this issue) present data from the Khibini Mountains (northern Russia) which show that the small-scale variability of the snow characteristics can be large even in areas with uniform geomorphology and topography. In contrast with common assumptions, variability of snow density was higher than that of snow depth.

Conde et al. (this issue) introduce a new methodology of mapping snow water equivalent (SWE) at high spatial resolution (up to $20 \mathrm{~m}$ ) from the Sentinel 1 and Synthetic Aperture Radar Interferometry. Validation of the methodology against measured SWE data from Finland provided promising results.

Parajka et al. (this issue) demonstrate the value of satellite snow data (MODIS) in the research of the links between snow 
characteristics and runoff. The analysis conducted in 145 catchments located in nine European countries showed that three to six snowmelt events occurred in the majority of catchments during a year. The mean difference between the snowmelt event beginning and the peak runoff was about three days. The snow line elevation during that time rose on average by $170 \mathrm{~m}$.

\section{ISOTOPIC APPROACHES}

A special focus is given to isotope measurements of precipitation and snowmelt water. Snowmelt is an important source of water recharging soils and triggering runoff generation. Stable isotopes of oxygen and hydrogen in water help to understand the movement of water in the hydrological cycle. While the sampling of rainwater and streams for stable isotopes is relatively easy, sampling of the meltwater (Penna et al., 2014) is still challenging. Vreča et al. (this issue) analyze the local-scale variability in isotopic composition of snowmelt water sampled in Slovenia by the passive capillary samplers (Penna et al., 2014). Analysis of variance and its source by ANOVA showed that due to the variability within the group of samplers (several samplers located close to each other), a large number of samplers $(>5)$ was needed to sample the snowmelt water.

Hürkamp et al. (this issue) present isotopic data from 18 snow profiles of two winter seasons at Mt. Zugspitze, Germany. They conclude that depth-integrated samples of entire $10 \mathrm{~cm}$ layers and point measurements in the same layers showed comparable isotopic compositions. Isotopic composition of the snowpack at the same sampling time in spatially distributed snow profiles was isotopically more similar than the composition observed at the same place at different times. Melting and refreezing were clearly identified as processes causing isotope fractionation in surficial, initial base or refrozen snow layers.

Rücker et al. (this issue) present a novel setup combining snowmelt lysimeters and water sampler for automatic sampling of the meltwater at daily time resolution. Simultaneous collection of rain samples provides stable isotope data to improve the identification of the contribution of snowmelt to runoff in a Swiss alpine catchment.

Šanda et al. (this issue) evaluate nine years of $\delta^{18} \mathrm{O}$ values in precipitation, soil water and groundwater in a small Czech mountain catchment and calculate the winter/summer recharge ratios of catchment groundwater, peat organic soil water, mineral hillslope soil water and baseflow. Isotopic mass balance of individual winters showed that precipitation in warmer winters was entirely transformed into outflow until the end of the winter season, leaving no significant water storage for potential drought periods.

\section{SNOWMELT MODELLING AND REMOTE SENSING DATA}

Riboust et al (this issue) revisit a simple degree-day model for integrating the satellite data and introduce a new calibration method for the snow model that also accounts for the hysteresis-behavior (Egli and Jonas, 2009) of snow cover during the accumulation and ablation processes. Incorporation of hysteresis between the snow-covered area (SCA) and snow water equivalent improved the SCA simulation. Model parameter sets calibrated jointly against SCA and runoff observations were more robust for simulating independent periods than the parameter sets obtained from discharge calibration only.

Piazzi et al. (this issue) investigate the effectiveness of snow multivariable data assimilation in a snow modelling system designed to provide the real time applications. A series of tests in the northwestern Italian Alps revealed the limitations and constraints in implementing a multivariate Ensemble Kalman Filter scheme in the framework of snow modelling and its performance in consistently updating the snowpack state. Combined assimilation of surface temperature, snow depth and albedo observations provided the best results in snowpack modeling.

Sorman et al. (this issue) explore the feasibility of probabilistic runoff forecasts using the probabilistic snow depletion curves derived from the satellite data (MODIS) in a snow dominated basin in Turkey. Estimated runoff values indicated good consistency with the forecasts based on the derived probabilistic snow depletion curves. The proposed framework can be easily adapted to other scarce networks or ungauged snowdominated mountain catchments to assist the decision makers responsible for the water management.

\section{CONCLUSIONS}

This thematic issue is a collection of current research efforts devoted to the role of snow in the hydrological cycle. The ten papers and the technical note present innovative methods of snow characteristics measurements, research of the relationships between snow and runoff, on the monitoring and evaluation of environmental tracers in the snow-related part of the hydrological cycle (precipitation, snowpack, soil moisture, groundwater, runoff). Modelling experiments showed how snow accumulation and melt modelling can be validated against snow and runoff observations. Data from remote sensing platforms and data assimilations procedures represent another very active field of research in contemporary snow hydrology. We thank the authors for their contributions and wish the readers of Journal of Hydrology and Hydromechanics much of new inspiration. Journal editor Dr. Lubomir Lichner is acknowledged for the very collegial and professional guidance in the process of compiling this collection of papers. We also thank all the reviewers who contributed to the improvement of the articles presented in the thematic issue. Massimiliano Zappa and Martin Šanda thank the Swiss National Science Foundation SNF (Joint Research Projects SCOPES, SREP-DROUGHT project, Grant IZ73Z0_152506) for the financial support of research activities conveyed in this thematic issue.

\section{IN MEMORIAM}

During the preparation of this special issue the editorial team learned that two scientists working on the topics presented in this compilation of articles passed away. It is therefore our wish to dedicate this issue to the memory of Associate Professor Dr. Robert Kirnbauer (Technical University of Wien, Austria) and of Dr. Stefan Pohl (University of Freiburg in Brisgau, Germany). Their work on snow processes (Pohl and Marsh, 2006) and snow modelling (Kirnbauer et al., 1994) represent a very important contribution for the understanding of snow as part of the hydrological cycle.

\section{REFERENCES}

Barnett, T.P., Adam, J.C., Lettenmaier, D.P., 2005. Potential impacts of a warming climate on water availability in snowdominated regions. Nature, 438, 7066, 303-309.

Barnhart, T.B., Molotch, N.P., Livneh, B., Harpold, A.A., Knowles, J.F., Schneider, D., 2016. Snowmelt rate dictates streamflow. Geophys. Res. Lett., 43, 8006-8016.

Berghuijs, W.R., Woods, R.A., Hrachowitz, M., 2014. A precipita- 
tion shift from snow towards rain leads to a decrease in streamflow. Nat. Clim. Change, 4, 583-586.

Egli, L., Jonas, T., 2009. Hysteretic dynamics of seasonal snow depth distribution in the Swiss Alps. Geophysical Research Letters, 36, 5 p. http://doi.org/10.1029/2008GL035545

Etchevers, P., Martin, E., Brown, R., Fierz, C., Lejeune, Y., Bazile, E., Boone, A., Dai, Y.-J., Essery, R., Fernandey, A., Gusey, Y., Jordan, R., Koren, V., Kowalczyk, E., Pyles, R.D., Schlosser, A., Shmakin, A.B., Smirnova, T.G., Strasser, U., Verseghy, D., Yamakazi, T., Yang, Z.-L., 2002. SNOWMIP, an intercomparison of snow models: comparison of simulated and observed internal state International. In: Proceedings of the International snow science workshop, Penticton, Canada, 29 Sep.-4 Oct. 2002, pp. 353-360.

Fraser, B., 2012. Melting in the Andes: Goodbye glaciers. Nature. 491, 180-182. DOI: 10.1038/491180a.

Godsey, S.E., Kirchner, J.W., Tague, C.L., 2014. Effects of changes in winter snowpacks on summer low flows: case studies in the Sierra Nevada, California, USA. Hydrol. Process., 28, 5048-5064. DOI: 10.1002/hyp.9943.

Gurtz, J., Baltensweiler, A., Lang, H., 1999. Spatially distributed hydrotope-based modelling of evapotranspiration and runoff in mountainous basins. Hydrol. Processes, 13, 2751-2768.

Hegg, C., McArdell, B.W., Badoux, A., 2006. One hundred years of mountain hydrology in Switzerland by the WSL. Hydrol. Process., 20, 371-376. DOI: 10.1002/hyp.6055.

Hock, R., 2003. Temperature index melt modelling in mountain areas. J. Hydrol., 282, 1-4, 104-115.

Jasechko, S., Birks, S.J., Gleeson, T., Wada, Y., Fawcett, P.J., Sharp, Z.D., McDonnell, J.J., Welker, J.M., 2014. The pronounced seasonality of global groundwater recharge. Water Resour. Res., 50, 8845-8867.

Jenicek, M., Seibert, J., Zappa, M., Staudinger, M., Jonas, T., 2016. Importance of maximum snow accumulation for summer low flows in humid catchments. Hydrol. Earth Syst. Sci., 20, 859874. DOI: 10.5194/hess-20-859-2016.

Kirnbauer, R., Bloschl, G., Gutknecht, D., 1994. Entering the era of distributed snow models. Nord. Hydrol., 25, 1-24.

Klemeš, V., 1990. The modelling of mountain hydrology: the ultimate challenge. In: Molar, L. (Ed.): Hydrology of Mountainous Areas. IAHS Press, Wallingford, Vol. 190, pp. 29-43.

Lemke, P., Ren, J., Alley, R.B., Allison, I., Carrasco, J., Flato, G., Fujii, Y., Kaser, G., Mote, P., Thomas, R.H., Zhang, T., 2007. Observations: Changes in Snow, Ice and Frozen Ground. In: Solomon, S., Qin, D., Manning, M., Chen, Z., Marquis, M., Averyt, K.B., Tignor, M., Miller, H.L. (Eds.): Climate Change 2007: The Physical Science Basis. Contribution of Working Group I to the Fourth Assessment Report of the Intergovernmental Panel on Climate Change. Cambridge University Press, Cambridge, United Kingdom and New York, NY, USA.

Mankin, J.S., Viviroli, D., Singh, D., Hoekstra, A.Y., Diffenbaugh, N.S., 2015. The potential for snow to supply human water demand in the present and future. Environmental Research Letters, 10, 11, 114016. DOI: 10.1088/1748-9326/10/11/114016.

Martinec, J., Rango, A., 1986. Parameter values for snowmelt runoff modelling. J. Hydrol., 84, 197-219.

Marty, C., Schlögl, S., Bavay, M., Lehning, M., 2017. How much can we save? Impact of different emission scenarios on future snow cover in the Alps. The Cryosphere, 11, 517-529. https://doi.org/10.5194/tc-11-517-2017.

Melikadze, G., Kapanadze, N., Todadze, M., 2013.Assessment the role of snow in hydrological cycle of the Borjomula-GudjaretiTskali rivers basin. Journal of Georgian Geophysical Society, Phys. Solid Earth., 16a, 19-24.

Parajka, J., Blöschl, G., 2008. The value of MODIS snow cover data in validating and calibrating conceptual hydrologic models. J. Hydrol., 358, 240-258. DOI: 10.1016/j.jhydrol.2008.06.006.

Penna, D., Ahmad, M., Birks, S.J., Bouchaou, L., Brenčič, M., Butt, S., Holko, L., Jeelani, G., Martínez, D.E., Melikadze, G., Shanley, J.B., Sokratov, S.A., Stadnyk, T., Sugimoto, A., Vreča, P., 2014. A new method of snowmelt sampling for water stable isotopes. Hydrol. Process., 28, 5637-5644. DOI: 10.1002/hyp.10273.

Pohl, S., Marsh, P., 2006. Modelling the spatial-temporal variability of spring snowmelt in an arctic catchment. Hydrol. Process., 20, 1773-1792. DOI: 10.1002/hyp.5955.

Šanda, M., Vitvar, T., Kulasová, A., Jankovec, J., Císlerová, M., 2014. Runoff formation in a humid, temperate headwater catchment using a combined hydrological, hydrochemical and isotopic approach (Jizera Mountains, Czech Republic). Hydrol. Process., 28, 3217-3229. DOI: 10.1002/hyp.9847.

Thirel, G., Salamon, P., Burek, P., Kalas, M., 2013. Assimilation of MODIS snow cover area data in a distributed hydrological model using the particle filter. Remote Sens., 5, $5825-5850$.

Van Loon, A.F., Ploum, S.F., Parajka, J., Fleig, A.K., Garnier, E., Laaha, G., Van Laanen, H.A.J., 2014. Hydrological drought types in cold climates: quantitative analysis of causing factors and qualitative survey of impacts. Hydrol. Earth Syst. Sci., 19, 1993-2016.

Vaughan, D.G., Comiso, J.C., Allison, I., Carrasco, J., Kaser, G., Kwok, R., Mote, P., Murray, T., Paul, F., Ren, J., Rignot, E., Solomina, O., Steffen, K., Zhang, T., 2013. Observations: Cryosphere. In: Stocker, T.F., Qin, D., Plattner, G.-K., Tignor, M., Allen, S.K., Boschung, J., Nauels, A., Xia, Y., Bex, V., Midgley, P.M. (Eds.): Climate Change 2013: The Physical Science Basis. Contribution of Working Group I to the Fifth Assessment Report of the Intergovernmental Panel on Climate Change. Cambridge University Press, Cambridge, United Kingdom and New York, NY, USA.

Viviroli, D., Archer, D.R., Buytaert, W., Fowler, H.J., Greenwood, G.B., Hamlet, A.F., Huang, Y., Koboltschnig, G., Litaor, I., López-Moreno, J.I., Lorentz, S., Schädler, B., Schreier, H., Schwaiger, K., Vuille, M., Woods, R., 2011. Climate change and mountain water resources: overview and recommendations for research, management and policy. Hydrology and Earth System Sciences, 15, 2, 471-504. DOI: 10.5194/hess-15-471-2011.

Vormoor, K., Lawrence, D., Schlichting, L., Wilson, D., Wong, W.K., 2016. Evidence for changes in the magnitude and frequency of observed rainfall vs. snowmelt driven floods in Norway. J. Hydrol., 538, 33-48. DOI:10.1016/j.jhydrol.2016.03.066.

Zappa, M., Vitvar, T., Rücker, A., Melikadze, G., Bernhard, L., David, V., Jans-Singh, M., Zhukova, N., Sanda, M., 2015. A Tri-National program for estimating the link between snow resources and hydrological droughts. Proc. IAHS, 369, 25-30, DOI: 10.5194/piahs-369-25-2015. 